\title{
Prevalence of Autoantibodies to the 65- and 67-kD Isoforms of Glutamate Decarboxylase in Insulin-dependent Diabetes Mellitus
}

\author{
J. Seissler, * J. Amann, * L. Mauch, "H. Haubruck, ' S. Wolfahrt, * S. Bieg, * W. Richter, * \\ R. Holl, ${ }^{*}$ E. Heinze, ${ }^{*}$ W. Northemann," and W. A. Scherbaum*' \\ ${ }^{*}$ Department of Internal Medicine I and ${ }^{\ddagger}$ Department of Pediatrics, University of Ulm, D-7900 Ulm; \\ 'Department of Molecular Biology, ELIAS Entwicklungslabor, Freiburg; and 'Department of Internal Medicine III, \\ University of Leipzig, 04103 Leipzig, Germany
}

\begin{abstract}
We investigated the presence of autoantibodies to baculovirusexpressed human recombinant 65- and 67-kD isoforms of glutamate decarboxylase $\left(\mathrm{GAD}_{65}\right.$ and $\left.\mathrm{GAD}_{67}\right)$ in insulin-dependent diabetes mellitus (IDDM). In the immunoprecipitation test using $\left[{ }^{35} \mathrm{~S}\right]$ methionine-labeled GADs antibodies to GAD $_{65}$ were detected in 13/15 (87\%) islet cell antibody (ICA)-positive and in 1/35 (2.9\%) ICA-negative first-degree relatives of patients with IDDM, in 6/11 (54.5\%) ICA-positive nondiabetic schoolchildren, and in $35 / 50(70 \%)$ patients with newly diagnosed IDDM. GAD $_{67}$ antibodies were positive only in five (33\%) of the ICA-positive relatives $(P<0.05)$ and in nine (18\%) IDDM patients at onset $(P<0.00001)$. After onset of IDDM antibodies to $\mathrm{GAD}_{65}$ and $\mathrm{GAD}_{67}$ declined but were still positive in 25 and $9.4 \%$ of subjects with long-standing IDDM (> $10 \mathrm{yr}$ ). In all study groups antibodies to $\mathrm{GAD}_{67}$ were only detected in $\mathrm{GAD}_{65}$ antibody-positive sera. An immunotrapping enzyme activity assay for $\mathrm{GAD}_{65}$ antibodies was positive in $64 / 75(85.3 \%)$ of sera that were GAD antibody positive in the immunoprecipitation test $(r=0.870, P<0.0001)$. In two (2.7\%) sera GAD $_{65}$ antibodies that block GAD enzyme activity were found. Our data suggest that antibodies to $\mathrm{GAD}_{65}$ but not to $\mathrm{GAD}_{67}$ represent sensitive markers for preclinical and overt IDDM. The immunotrapping assay here described represents a valuable technique for specific and sensitive screening for GAD antibodies. (J. Clin. Invest. 1993. 92:1394-1399.) Key words: glutamic acid decarboxylase $\bullet$ autoantibodies $\bullet$ insulin-dependent diabetes mellitus • islet cell antibodies
\end{abstract}

\section{Introduction}

Insulin-dependent diabetes mellitus (IDDM) ${ }^{1}$ is strongly associated with the appearance of islet cell-specific autoantibodies, reflecting the autoimmune-mediated destruction of the pancre-

Address correspondence to W. A. Scherbaum, M.D., Department of Internal Medicine III, University of Leipzig, Johannisallee 32, 04103 Leipzig, Germany.

Received for publication 26 January 1993 and in revised form 5 April 1993.

1. Abbreviations used in this paper: AET, 2-aminoethylisothiouronium bromide; $\mathrm{GAD}_{65}, \mathrm{GAD}_{67}, 65$ - and $67-\mathrm{kD}$; glutamate decarboxylase; ICA, islet cell antibodies; 64K, 64-kD islet cell protein; IDDM, insulindependent diabetes mellitus; IPT, immunoprecipitation test; ITA, immunotrapping assay; PLP, pyridoxal 5-phosphate.

J. Clin. Invest.

(c) The American Society for Clinical Investigation, Inc.

$0021-9738 / 93 / 09 / 1394 / 06 \$ 2.00$

Volume 92, September 1993, 1394-1399 atic beta cells. Cytoplasmic islet cell antibodies (ICA) as well as antibodies to a $64-\mathrm{kD}$ islet cell protein $(64 \mathrm{~K})$ have been detected in 70-90\% of individuals before and at the time of diagnosis of IDDM (1-4). In prospective studies only a subgroup of ICA-positive nondiabetic individuals, especially those with high ICA titers and complement-fixing ICA, developed IDDM $(5,6)$. In first-degree relatives and ICA-positive nondiabetic subjects antibodies to the $64 \mathrm{~K}$ antigen were detected early in the preclinical course of IDDM and were strongly correlated with rapid progression to overt diabetes $(7,8)$. Therefore, the accurate determination of antibodies to the $64 \mathrm{~K}$ antigen would be of particular interest to identify subjects at high risk for the development of IDDM. A large-scale detection of $64 \mathrm{~K}$ antibodies has been hampered by the laborious technique of the immunoprecipitation of $\left[{ }^{35} \mathrm{~S}\right]$ methionine-labeled islet cells preparations.

The target antigen of the $64 \mathrm{~K}$ antibodies has been identified as the enzyme glutamate decarboxylase (GAD), which synthesizes $\gamma$-aminobutyric acid (GABA) from glutamic acid (9). GAD exists at least in two different isoforms with molecular sizes of $65 \mathrm{kD}\left(\mathrm{GAD}_{65}\right)$ and $67 \mathrm{kD}\left(\mathrm{GAD}_{67}\right)$ encoded by two distinct genes $(10,11)$. It was shown that $\mathrm{GAD}_{65}$ corresponds to the $64 \mathrm{~K}$ antigen and both isoforms are recognized by sera from patients with $\operatorname{IDDM}(12,13)$. Population-based data on the frequency of antibodies to human $\mathrm{GAD}_{67}$ are scanty. Thus, the importance of antibodies to $\mathrm{GAD}_{67}$ for IDDM is still unclear.

Because both isoforms of GAD are expressed in brain neurons $(12,13)$ several studies used brain preparations to determine antibodies to GAD by an immunotrapping enzyme activity assay (ITA) (14-16). In contrast to 64K antibodies, antibodies to GAD, as measured in the ITA, were detected in only $25-37 \%$ of newly diagnosed patients with IDDM. It has been suggested that these controversial data might be due to differences in the sensitivity of the assays or that only a part of the immunoreactivity to the $64 \mathrm{~K}$ islet protein is directed to GAD. In none of these reports has a direct comparison of the immunoprecipitation test and the ITA been performed to address this question.

In the present study human recombinant GAD expressed in the baculovirus system was used to determine autoantibodies to $\mathrm{GAD}_{65}$ and $\mathrm{GAD}_{67}$. We analyzed for the first time the prevalence of antibodies to $\mathrm{GAD}_{65}$ and $\mathrm{GAD}_{67}$ in individuals at high risk for IDDM, at the onset of the disease, and in patients with a long duration of IDDM. In our approach we compared the results of the conventional immunoprecipitation test with the GAD immunotrapping enzyme activity assay in individual sera. This made it possible for us to determine antibodies which block GAD enzyme activity and evaluate the diagnostic value of the different immunoassays regarding the detection of antibodies to GAD. 


\section{Methods}

Human sera. We studied sera from 50 patients with IDDM, obtained within the first month of diagnosis, and 77 sera from patients with a duration of IDDM from 0.5 to $40 \mathrm{yr}$. In addition, subjects at high risk for the development of IDDM were evaluated for GAD antibodies. We assayed GAD antibodies in 11 persistently ICA-positive nondiabetic schoolchildren without a family history of IDDM from the UlmFrankfurt population study $(8,17,18)$ and 50 nondiabetic first-degree relatives of patients with IDDM. Among the 50 relatives, 15 were positive for circulating ICA at high level (> $40 \mathrm{JDF}-\mathrm{U}) .60 \mathrm{ICA}$-negative sera from normal individuals without a family history for IDDM were used as control samples. The sera were coded, stored at $-20^{\circ} \mathrm{C}$, and tested in a blinded way in each of the assays. Informed consent was obtained from all patients and control subjects.

Detection of cytoplasmic ICA. Cytoplasmic ICA were analyzed by the indirect immunofluorescence tests on cryostat sections of human pancreas from an organ donor with blood group O (19). ICA were expressed in Juvenile Diabetes Foundation (JDF) Units (IDW ICA Proficiency Program, Lab ID No 116). The detection limit of the assay in our laboratory was 5 JDF-U.

Antigen expression and preparation. $\mathrm{GAD}_{65}$ and $\mathrm{GAD}_{67} \mathrm{cDNA}$ clones were constructed by inserting full-length human $\mathrm{GAD}_{65}$ and $\mathrm{GAD}_{67}$ cDNAs into the baculovirus vector pVL1393 (Invitrogen, San Diego, CA). The cDNA clones were cotransfected with the wild-type Autographa californica virus and the recombinant baculovirus clones were isolated as described (20). Spodoptera frugiperda (Sf9) cells were infected with the recombinant baculovirus clones and cultured in SF900 medium (Gibco Laboratories, Grand Island, NY) supplemented with $0.04 \% \mathrm{FCS}$ for $48 \mathrm{~h}$. Then cells were harvested and homogenized in $20 \mathrm{mM}$ potassium phosphate, $\mathrm{pH} 7.0 ; 2$ mM EDTA; $2 \mathrm{mM}$ PMSF; $5 \mu \mathrm{g} / \mathrm{ml}$ Leupeptin; $1 \mathrm{mM} 2$-aminoethylisothiouronium bromide (AET); and $0.2 \mathrm{mM}$ pyridoxal 5-phosphate (PLP) (buffer A). For immunoprecipitation experiments infected $\mathrm{Sf} 9$ cells were cultured in Grace's medium (Gibco Laboratories) for $36 \mathrm{~h}$, labeled with [ $\left.{ }^{35} \mathrm{~S}\right]-$ methionine $\left(200 \mu \mathrm{Ci} / 5 \times 10^{6}\right.$ cells $)$ for $6 \mathrm{~h}$, and homogenized in buffer A. The homogenates were centrifugated at $33,000 \mathrm{~g}$ for $30 \mathrm{~min}$ to separate the soluble cytosolic fraction in the supernatant and the particulate fraction in the pellet. Cell pellets were stored at $-80^{\circ} \mathrm{C}$ until further preparation.

Immunoprecipitation test (IPT). The IPT was performed with minor modifications as described previously (8). The particulate fractions of $\left[{ }^{35} \mathrm{~S}\right]$ methionine-labeled Sf 9 cells were resuspended in $20 \mathrm{mM}$ potassium phosphate, $150 \mathrm{mM} \mathrm{NaCl}, \mathrm{pH} 7.2 ; 2$ mM EDTA; $2 \mathrm{mM}$ PMSF; $1 \%$ Trasylol; and $1 \%$ Triton $\mathrm{X}-100$ for $2 \mathrm{~h}$ at $4{ }^{\circ} \mathrm{C}$ followed by centrifugation at $33,000 \mathrm{~g}$ for $30 \mathrm{~min}$ to obtain the membrane fraction (MF) in the supernatant. MFs containing equal amounts of radiolabeled $\mathrm{GAD}_{65}$ or $\mathrm{GAD}_{67}$ were incubated with a pool of normal human serum $\left(25 \mu \mathrm{l} / 100 \mu \mathrm{l}\right.$ lysate, equivalent to $5 \times 10^{5}$ infected Sf9 cells $)$ for $6 \mathrm{~h}$ and then preabsorbed with protein A-Sepharose (Pharmacia Inc., Freiburg, Germany). $100 \mu \mathrm{l}$ of the precleared extracts were precipitated with $25 \mu$ l test serum, followed by an adsorption of the immunocomplexes on protein A-Sepharose. After extensive washing the bound proteins were eluted with $65 \mathrm{mM}$ Tris/ $\mathrm{HCl}, \mathrm{pH} 6.8 ; 2 \%$ SDS; and 5\% mercaptoethanol and analyzed by fluorography. Fluorograms were analyzed by densitrometry (LKB Ultroscan; Pharmacia Inc.). In each experiment a positive and a negative reference serum were included as internal controls. Peak areas compared with the positive serum were taken as a measure of the GAD antibody level and expressed in percent of the positive standard serum. Values above mean +3 SD of 60 control subjects were considered positive. Using this assay in the First GAD Antibody Workshop, we achieved a specificity of $100 \%$, a sensitivity of $83.3 \%$, and a validity of $87.5 \%$.

$I T A$. The particulate fraction of $\mathrm{Sf} 9$ cells expressing $\mathrm{GAD}_{65}$ was resuspended in buffer $\mathrm{A}, \mathrm{pH} 7.0$, supplemented with $1 \%$ Triton $\mathrm{X}-100$ for $2 \mathrm{~h}$ at $4^{\circ} \mathrm{C}$. After centrifugation at $33,000 \mathrm{~g}$ for $30 \mathrm{~min}$, the supernatant was used to perform the ITA. $100 \mu \mathrm{l}$ of serum were incubated with $200 \mu \mathrm{l}$ reconstituted protein A-Sepharose beads for $2 \mathrm{~h}$ at $20^{\circ} \mathrm{C}$. The beads were washed four times with $50 \mathrm{mM}$ potassium phosphate, $\mathrm{pH}$ 7.0; $1 \mathrm{mM}$ EDTA; $1 \mathrm{mM}$ AET; $0.2 \mathrm{mM}$ PLP; and 0.5\% Triton X-100, $400 \mu \mathrm{l}$ of MF (corresponding to a GAD activity of $0.5 \mathrm{mU}$ ) was added for $12 \mathrm{~h}$ at $4^{\circ} \mathrm{C}$. After another washing step, $400 \mu 150 \mathrm{mM}$ potassium phosphate buffer, pH 7.0, with $1 \mathrm{mM}$ EDTA, $1 \mathrm{mM}$ AET, $1 \mathrm{mM}$ glutamic acid, 0.2 mM PLP (buffer B) was added, and the samples were divided into two aliquots and the precipitated enzymatic GAD activity was determined. The immunotrapped GAD activity was calculated by subtracting the background counts using PBS instead of serum and was expressed in $\mu \mathrm{U}$ immunotrapped by $50 \mu \mathrm{l}$ serum. Sera were considered GAD antibody positive if the immunoprecipitated GAD activity was above the mean +3 SD of 60 control subjects.

Determination of GAD enzyme activity. GAD activity was analyzed using a modification of the protocol described by Miller et al. (21). Aliquots of homogenates or immunocomplexes were diluted in buffer B to a total volume of $200 \mu$ l with a final concentration of $1 \mathrm{mM} /$ liter L-glutamic acid and a specific radioactivity of $\mathrm{L}\left[1-{ }^{14} \mathrm{C}\right]$ glutamic acid (Amersham Corp., Braunschweig, Germany) of $500 \mu \mathrm{Ci} / \mathrm{mmol}$ for assaying of GAD activity in the cell extracts and $1,000 \mu \mathrm{Ci} / \mathrm{mmol}$ in the ITA, respectively. After adding the reaction mixture into glass tubes, a filter paper soaked with $50 \mu \mathrm{l} 1 \mathrm{M}$ hyamine hydroxide was placed into the tubes. The tubes were closed and incubated for $1 \mathrm{~h}$ at $37^{\circ} \mathrm{C}$. The reaction was stopped by injecting $1 \mathrm{ml} 5 \mathrm{~N}$ sulphuric acid followed by an equilibration period of $1 \mathrm{~h}$ to allow complete adsorption of released ${ }^{14} \mathrm{CO}_{2}$. Then the ${ }^{14} \mathrm{CO}_{2}$ trapped to the filter paper was measured in a liquid scintilation counter. GAD enzyme activity was expressed in $\mathrm{U} / \mathrm{mg}$ protein. One unit was defined as the formation of 1 $\mu \mathrm{mol} \mathrm{CO} / \mathrm{min}$ under standard assay conditions.

Statistical analysis. The significance of differences between observations was tested using the Wilcoxon test, the chi-square test with Yates' correction, or the Fisher's exact test, where appropriate. The correlations of antibody levels were tested by linear-regression analysis.

\section{Results}

Autoimmunity to GAD in IDDM is mainly directed to $G A D_{65}$. Human recombinant $G A D_{65}$ and $G_{A D}$ were highly expressed in a baculovirus system. The enzymatic activity of

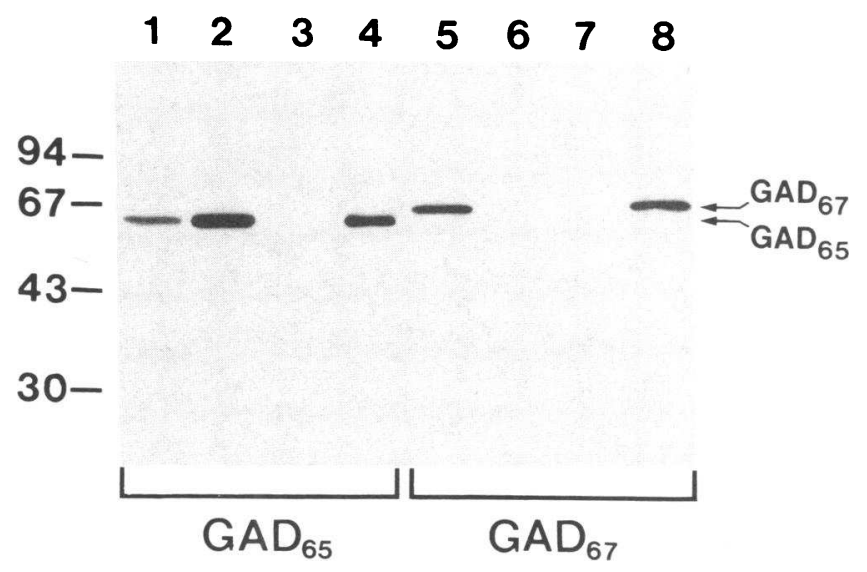

Figure 1. Immunoprecipitation of $\left[{ }^{35} \mathrm{~S}\right]$ methionine-labeled human recombinant $\mathrm{GAD}_{65}$ and $\mathrm{GAD}_{67}$. Membrane fractions of $\mathrm{GAD}_{65}$ (lanes 1-4) and $\mathrm{GAD}_{67}$ (lanes 5-8) were immunoprecipitated with two sera from newly diagnosed IDDM patients (patient 1 , lanes $I$ and 6, patient 2, lanes 2 and 5) and a serum from a control subject (lanes 3 and 7). Patient 1 was positive for antibodies to $G_{A D}$ but negative for antibodies to $\mathrm{GAD}_{67}$, patient 2 had antibodies to $\mathrm{GAD}_{65}$ and $\mathrm{GAD}_{67}$. As positive controls the immunoprecipitation with the mouse monoclonal antibody GAD 1 (lane 4 ) and the rabbit antiserum K-2 (lane 8 ) are shown. Molecular weight markers $\left(M_{\mathrm{r}}\right.$ $\times 10^{-3}$ ) are indicated on the left margin. 


\begin{tabular}{|c|c|c|c|c|c|c|}
\hline \multirow[b]{2}{*}{ Study groups } & \multirow{2}{*}{$\begin{array}{l}\text { Number of } \\
\text { sera tested }\end{array}$} & \multicolumn{2}{|c|}{ Sex } & \multicolumn{3}{|c|}{ Age } \\
\hline & & Female & Male & Mean & Median & Range \\
\hline Control subjects & 60 & 34 & 26 & 23.5 & 22 & $8-38$ \\
\hline \multicolumn{7}{|l|}{ High risk subjects } \\
\hline \multicolumn{7}{|l|}{ First degree relatives } \\
\hline ICA negative & 35 & 17 & 18 & 20.0 & 21 & 4-37 \\
\hline ICA positive & 15 & 9 & 6 & 25.0 & 23 & $15-59$ \\
\hline ICA + schoolchildren & 11 & 4 & 7 & 12.0 & 13 & $8-15$ \\
\hline \multicolumn{7}{|l|}{ Patients with IDDM } \\
\hline New onset IDDM & 50 & 23 & 27 & 25.1 & 25 & $5-41$ \\
\hline \multicolumn{7}{|l|}{ Duration of IDDM } \\
\hline $0.5-2 \mathrm{yr}$ & 21 & 9 & 12 & 22.2 & 24 & $6-38$ \\
\hline $2-10 \mathrm{yr}$ & 24 & 12 & 12 & 26.0 & 29 & $3-47$ \\
\hline$>10 \mathrm{yr}$ & 32 & 15 & 17 & 35.1 & 36 & $18-61$ \\
\hline
\end{tabular}

crude lysates of $\mathrm{Sf} 9$ cells expressing $\mathrm{GAD}_{65}$ and $\mathrm{GAD}_{67}$ was 155 and $169 \mathrm{mU} / \mathrm{mg}$ protein, respectively. Both GADs were immunoprecipitated by IDDM sera. Recombinant $\mathrm{GAD}_{65}$ was recognized by the mouse monoclonal antibodies GAD1 (ATTC no. HB184; reference 22) and recombinant GAD $_{67}$ was precipitated by the K-2 antiserum (23), which binds to the 67-kD isoform of GAD (Fig. 1). The characterization of study groups and the prevalences of antibodies to $\mathrm{GAD}_{65}, \mathrm{GAD}_{67}$, and ICA in the different study groups are summarized in Ta- bles I and II. In the immunoprecipitation test, antibodies to $\mathrm{GAD}_{65}$ were present in $35(70 \%)$ of 50 newly diagnosed IDDM patients, whereas $\mathrm{GAD}_{67}$ antibodies were detected in only 9 (18\%) subjects $(P<0.00001)$. In addition, antibodies to $\mathrm{GAD}_{67}$ were observed only in $\mathrm{GAD}_{65}$-positive sera. At the onset of IDDM, ICA were positive in $38(76 \%)$ sera (mean ICA level 157 $\pm 304 \mathrm{JDF}-\mathrm{U}$, range 10-1,280). No correlation could be demonstrated between the levels of ICA and antibodies to $\mathrm{GAD}_{65}$ or $\mathrm{GAD}_{67}$. Out of 12 ICA-negative sera from patients

Table II. Prevalence of Antibodies to $G A D_{65}$ and $G A D_{67}$ and Islet Cell Antibodies within the Study Groups

\begin{tabular}{|c|c|c|c|c|c|}
\hline \multirow[b]{2}{*}{ Study groups } & \multirow[b]{2}{*}{$\begin{array}{l}\text { Number of } \\
\text { sera tested }\end{array}$} & \multirow[b]{2}{*}{ ICA } & \multicolumn{2}{|c|}{ Immunoprecipitation test } & \multirow{2}{*}{$\begin{array}{c}\begin{array}{c}\text { Immunotrapping } \\
\text { assay }\end{array} \\
\begin{array}{c}\mathrm{GAD}_{65} \\
\text { antibody }\end{array}\end{array}$} \\
\hline & & & $\begin{array}{l}\mathrm{GAD}_{65} \\
\text { antibody }\end{array}$ & $\begin{array}{l}\mathrm{GAD}_{67} \\
\text { antibody }\end{array}$ & \\
\hline & & $J D F-U$ & & & \\
\hline Control subjects & 60 & 0 & 0 & 0 & 0 \\
\hline \multicolumn{6}{|l|}{ High risk subjects } \\
\hline \multicolumn{6}{|l|}{ First degree relatives } \\
\hline ICA positive & 15 & $\begin{array}{l}15 \\
(331 \pm 211)\end{array}$ & $\begin{array}{l}13(86.7 \%) \\
(143 \pm 85)\end{array}$ & $\begin{array}{c}5(33.3 \%) \\
(102 \pm 105)\end{array}$ & $\begin{array}{l}12(80.0 \%) \\
(117 \pm 89)\end{array}$ \\
\hline ICA negative & 35 & 0 & $\begin{array}{c}1(2.9 \%) \\
(23)\end{array}$ & 0 & 0 \\
\hline ICA + schoolchildren & 11 & $\begin{array}{l}11 \\
(52 \pm 45)\end{array}$ & $\begin{array}{l}6(54.6 \%) \\
(34 \pm 20)\end{array}$ & 0 & $\begin{array}{l}6(54.6 \%) \\
(19 \pm 15)\end{array}$ \\
\hline \multicolumn{6}{|l|}{ Patients with IDDM } \\
\hline New onset IDDM & 50 & $\begin{array}{l}38(76.0 \%) \\
(157 \pm 304)\end{array}$ & $\begin{array}{c}35(70.0 \%) \\
(74 \pm 66)\end{array}$ & $\begin{array}{c}9(18.0 \%) \\
(64 \pm 72)\end{array}$ & $\begin{array}{c}27(54.0 \%) \\
(56 \pm 61)\end{array}$ \\
\hline \multicolumn{6}{|l|}{ Duration of IDDM } \\
\hline $0.5-2 \mathrm{yr}$ & 21 & $\begin{array}{r}8(38.1 \%) \\
(117 \pm 103)\end{array}$ & $\begin{array}{c}7(33.3 \%) \\
(131 \pm 90)\end{array}$ & $\begin{array}{c}3(14.3 \%) \\
(14 / 23 / 210)\end{array}$ & $\begin{array}{l}6(28.6 \%) \\
(146 \pm 86)\end{array}$ \\
\hline $2-10 \mathrm{yr}$ & 24 & $\begin{array}{l}6(25.0 \%) \\
(90 \pm 56)\end{array}$ & $\begin{array}{l}5(20.8) \\
(76 \pm 99)\end{array}$ & $\begin{array}{l}2(8.3 \%) \\
(16 / 100)\end{array}$ & $\begin{array}{l}5(20.8 \%) \\
(88 \pm 90)\end{array}$ \\
\hline$>10 \mathrm{yr}$ & 32 & $\begin{array}{l}2(9.5 \%) \\
(60 / 160)\end{array}$ & $\begin{array}{l}8(25.0 \%) \\
(82 \pm 79)\end{array}$ & $\begin{array}{c}3(9.4 \%) \\
(13 / 67 / 136)\end{array}$ & $\begin{array}{l}8(25.0 \%) \\
(50 \pm 60)\end{array}$ \\
\hline
\end{tabular}

Results obtained with the ITA are expressed in $\mu \mathrm{U}$ of enzyme activity immunotrapped by $50 \mu \mathrm{l}$ serum; values $>6.7 \mu \mathrm{U}$ are taken as positive. GAD antibody levels in the IPT are demonstrated as \% of the GAD antibody positive reference serum. Antibody levels (mean + SD) are given in parentheses (if less than four subjects were positive the measured values are indicated). 
with new onset of IDDM, $\mathrm{GAD}_{65}$ and $\mathrm{GAD}_{67}$ antibodies were found in $7(58.3 \%)$ and $1(8.3 \%)$ subjects, respectively. Thus, $26 / 50(52 \%)$ of the patients had ICA as well as antibodies to $\mathrm{GAD}_{65}$ and $45 / 50(90 \%)$ were found to be positive for one of these markers. Among the 60 controls neither antibodies to $\mathrm{GAD}_{65}$, antibodies to $\mathrm{GAD}_{67}$, or ICA were detected.

The prevalence of each of the antibody specificities tested declined after the onset of IDDM (Table II). After 0.5-2 yr, antibodies to $\mathrm{GAD}_{65}$ as well as ICA were decreased compared with newly diagnosed patients with IDDM $(P<0.05)$. IDDM patients tested up to $10 \mathrm{yr}$ after onset of IDDM exhibited a highly significant reduction of antibodies to $\mathrm{GAD}_{65}$ and ICA ( $P$ $<0.0005)$. In long-term diabetic patients $(11-40 \mathrm{yr})$, the frequency of antibodies to $\operatorname{GAD}_{65}(8 / 32,25.0 \%)$ was slightly increased compared with the IDDM patients 2-10 yr after onset of IDDM. The prevalance of antibodies to $\mathrm{GAD}_{67}$ declined from $18 \%$ at diagnosis to $9.4 \%$ after long duration of IDDM, but this did not reach the level of significance.

High prevalance of GAD antibodies in subjects with increased risk for IDDM. 6 of 11 (54.5\%) nondiabetic individuals with persistent ICA (mean 52 \pm 45 JDF-U, range 10-160) without a family history of IDDM possessed antibodies to $\mathrm{GAD}_{65}$. All of these six sera had been found $64 \mathrm{~K}$ antibody positive in the IPT using labeled islets (8). $13(86.7 \%)$ of 15 first-degree relatives with ICA levels $>40$ JDF-U (mean $331 \pm 211$ JDF-U, range 80-640) had antibodies to $\mathrm{GAD}_{65}$, whereas only $5(33.3 \%)$ of them were $\mathrm{GAD}_{67}$ antibody positive $(P<0.05)$. The level of the $\mathrm{GAD}_{65}$ antibodies $(143 \pm 85 \%)$ was significantly increased compared with new onset IDDM patients $(74 \pm 66 \%)(P<0.005)$. In 1 of $35(2.9 \%)$ ICA-negative relatives, antibodies to $\mathrm{GAD}_{65}$ were observed. Antibodies to $\mathrm{GAD}_{67}$ were only detected in $\mathrm{GAD}_{65}$ antibody-positive sera. Antibodies to $\mathrm{GAD}_{67}$ were negative in all ICA-negative first-degree relatives and in 11 ICA-positive schoolchildren.

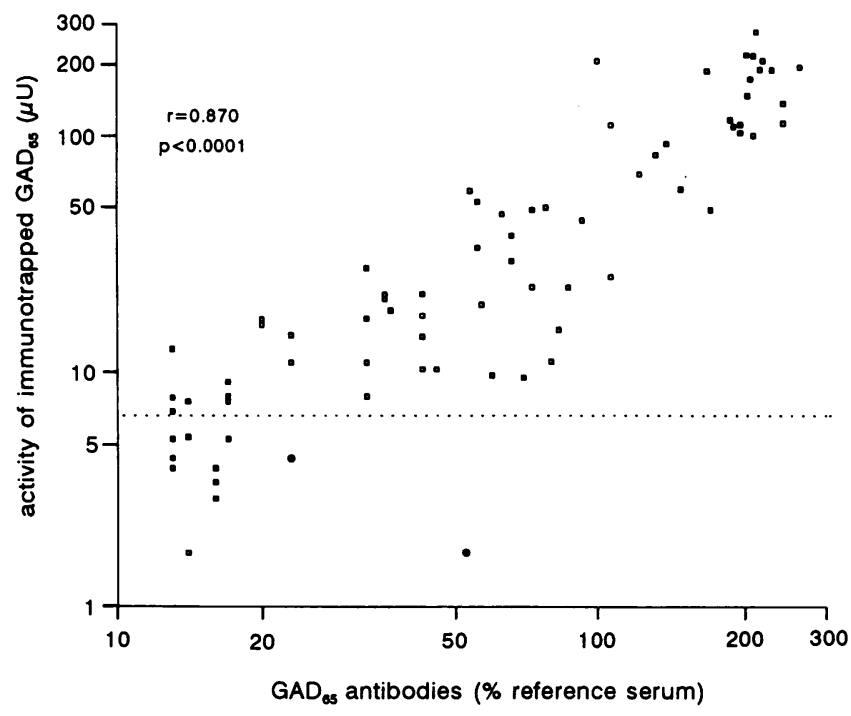

Figure 2. Correlation of the ITA and the conventional IPT for the detection of antibodies to human $\mathrm{GAD}_{65}$. The results of $75 \mathrm{GAD}_{65}$ antibody-positive subjects are demonstrated. The levels of GAD antibodies in the ITA are expressed as immunotrapped enzyme activity $(\mu \mathrm{U})$ per $50 \mu \mathrm{l}$ serum. Results of the immunoprecipitation test are given in \% of the GAD antibody-positive reference serum. The dashed line represents the mean +3 SD of healthy controls $(6.7 \mu \mathrm{U})$. $(\bullet)$ GAD blocking antibodies.
The ITA reveals GAD antibodies of high specificity and sensitivity. All sera from the different study groups were tested in our newly developed ITA using recombinant $\mathrm{GAD}_{65}$. The mean +1 SD of the immunotrapped GAD activity of 60 control subjects was $2.32+1.46$ ( range $0.44-5.77 \mu \mathrm{U}$ ). Binding of $>6.7 \mu \mathrm{U}($ mean $+3 \mathrm{SD})$ was considered as immunotrapped $\mathrm{GAD}_{65}$ antibody positive. The intra- and interassay coefficients of variation were $10.2 \%(n=8)$ and $15.7 \%(n=8)$, respectively. Antibodies to $\mathrm{GAD}_{65}$, detected by the ITA were found in 64 of $75(85.3 \%)$ of the $\mathrm{GAD}_{65}$ antibody-positive subjects, as characterized in the IPT (Table 1). The mean level of the positive subjects was $71 \pm 75 \mu \mathrm{U}$ (range $6.8-277.0 \mu \mathrm{U}$ ). There was a strong correlation between the levels of $\mathrm{GAD}_{65}$ antibodies determined in the IPT and the level of immunotrapped GAD activity (Fig. 2) $(r=0.870, P<0.0001)$. None of the $\mathrm{GAD}_{65}$ antibody-negative subjects or of the normal controls exceeded the normal range (mean $+3 \mathrm{SD}$ of controls). Compared with the conventional IPT as the gold-standard technique, the ITA achieved values of $100 \%$ for specificity and $87.2 \%$ for sensitivity.

GAD-blocking antibodies appear in only a minority of individuals. GAD antibodies that block the enzyme activity were detected by analyses of the results of the IPT compared with the ITA in individual sera. Regarding $11 \mathrm{GAD}_{65}$ antibody-positive sera, which were negative in the ITA, 9 turned out to be just weakly $\mathrm{GAD}_{65}$ antibody positive $\left(\mathrm{GAD}_{65}\right.$ antibody level $13-$ $17 \%$ of the reference serum) (Fig. 2). Thus, only 2 of 75 (2.7\%) $\mathrm{GAD}_{65}$ antibody-positive sera may possess high titers of GAD antibodies that inhibited the enzyme activity.

\section{Discussion}

Antibodies to the $64 \mathrm{~K}$ islet cell protein have been described as an early and reliable serological marker to predict future development of IDDM in nondiabetic individuals. The identification of the $64 \mathrm{~K}$ protein as GAD and the recognition of at least two isoforms have raised the question as to which isoform would be the major antigen in the natural history of IDDM. To address this question we expressed human $\mathrm{GAD}_{65}$ and $\mathrm{GAD}_{67}$ in the baculovirus system to produce a homogeneous source of native antigens. This allowed us to overcome the disadvantages of the antigen shortage, differences in the cell preparation, and antigen purity, which were critical to the conventional IPT using isolated islets.

The observed prevalence of $86.7 \%$ of antibodies to $\mathrm{GAD}_{65}$ in ICA-positive relatives and $70 \%$ in patients with recent onset of IDDM was similar to the frequency of $64 \mathrm{~K}$ antibodies using labeled islets $(4,24)$. In addition, we detected antibodies to $\mathrm{GAD}_{65}$ in all $64 \mathrm{~K}$ antibody-positive schoolchildren (8). These findings support the contention that $\mathrm{GAD}_{65}$ is identical to the $64 \mathrm{~K}$ islet cell protein $(9,13)$. Consistent with studies suggesting that antibodies to the $64 \mathrm{~K}$ antigen indicate an increased risk for the development of IDDM (7), we found that three of the six $\mathrm{GAD}_{65}$ antibody-positive schoolchildren developed overt IDDM after a follow-up of 16-30 mo (8). In our study the prevalence and levels of antibodies to $\mathrm{GAD}_{65}$ were higher in ICA-positive relatives compared with patients with new onset IDDM. This suggests that the autoimmune reaction to GAD appears at an early stage preceeding the diagnosis of IDDM.

Until now, only limited data are available on the presence of antibodies to $\mathrm{GAD}_{67}$ in IDDM. We detected antibodies to $\mathrm{GAD}_{67}$ in only $33.3 \%$ of ICA-positive relatives and in $18 \%$ of 
patients with newly diagnosed IDDM. The surprising difference in the antibody reactivity to $\mathrm{GAD}_{65}$ and $\mathrm{GAD}_{67}$ emphasizes the relevance of the diversity of the two isoforms of GAD. The amino acid sequence identity between human $\mathrm{GAD}_{65}$ and $\mathrm{GAD}_{67}$ is $\sim 65 \%$, with the highest diversity for the amino-terminal 120 amino acids (11). This may either suggest that the majority of antibodies to GAD are primarily directed to the amino terminus or the diversity of the amino acid sequence between $\mathrm{GAD}_{65}$ and $\mathrm{GAD}_{67}$ leads to conformational changes of the GAD protein. The importance of the three-dimensional structure of GAD is emphasized by the fact that most of the IDDM sera do not react with denaturated $\operatorname{GAD}_{65}(9)$. In contrast to the present data, Kaufman et al. (13) and Deaizpurua et al. (25) reported on antibodies to $\mathrm{GAD}_{67}$ in 9 of 12 and in 7 of 9 preclinical subjects as well as in 3 of 3 and in 6 of 13 patients with IDDM, respectively. Various explanations could be found for this disagreement. First, these authors used bacterially expressed rat or mouse $\mathrm{GAD}_{67}$. Despite a high homology of rat, mouse, and human $\mathrm{GAD}_{67}(11)$ the discrepancy could be due to the species differences, since different antigenic enzyme forms of GAD have been described $(26,27)$. Second, Kaufman et al. (13) used a mixture of [ $\left.{ }^{35} \mathrm{~S}\right]$ methionine-labeled $\mathrm{GAD}_{65}$ and $\mathrm{GAD}_{67}$ in the IPT, which could lead to unspecific precipitation of GAD isoforms. There is evidence that monoclonal GAD antibodies that recognize only $\mathrm{GAD}_{65}$ coprecipitate both isoforms from brain preparations $(24,28)$. This suggests that $\mathrm{GAD}_{65}$ and $\mathrm{GAD}_{67}$ can tightly associate, probably by forming heterodimers. The higher frequency of antibodies to $\mathrm{GAD}_{67}$ observed by Diaizpurua et al. (25) may be explained by the application of an ELISA for the detection of the autoantibodies. International workshops on the standardization of insulin autoantibody measurement have clearly shown that solid-phase and fluid-phase assays detect different antibody populations with different affinities (29). Insulin autoantibodies were more frequently detectable by ELISA but antibodies measured by fluid-phase assays were much better correlated with IDDM (29). According to our data, $\mathrm{GAD}_{67}$ is only a minor target antigen in IDDM. This is in line with data suggesting that human islets express only $\mathrm{GAD}_{65}$ but not $\mathrm{GAD}_{67}(11)$. The autoimmune reaction in IDDM may be primarily directed against $\mathrm{GAD}_{65}$ and subgroups of the polyclonal natural autoantibodies could recognize common epitopes of the two isoforms of GAD. This assumption is supported by the fact that our human monoclonal GAD antibodies (MICA 1-6) derived from a patient with newly diagnosed IDDM all recognized only the $\mathrm{GAD}_{65}$ isoform (30). Furthermore, in the present study, antibodies to $\mathrm{GAD}_{67}$ were restricted to patients with $\mathrm{GAD}_{65}$ immunoreactivity. Direct epitope studies will be required to fully support this hypothesis.

Analogous to ICA, the prevalence of antibodies to $\mathrm{GAD}_{65}$ and $\mathrm{GAD}_{67}$ declined in the first years after the onset of IDDM. This has also been shown for $64 \mathrm{~K}$ antibodies ( 31 ). However, in our study, antibodies to $\mathrm{GAD}_{65}$ were still detectable in $25 \%$ of subjects with a long duration of IDDM. As initially reported by Kaufman et al. (13), we here observed that six of eight patients with long-standing IDDM and antibody reactivity to $\mathrm{GAD}_{65}$ had a peripherial diabetic neuropathy (data not shown). The high frequency of GAD antibodies in these patients could be explained by the reappearance of antibodies to GAD caused by a repeated presentation of GAD to the immune system by the affection of GABA synthesizing neurons during the development of diabetic neuropathy (32).
After the identification of GAD as a target antigen in IDDM, antibodies to GAD were detected in several studies by measuring the immunotrapping enzyme activity. The prevalence of antibodies to GAD was reported to be as low as 25$38 \%$ using rat (14), pig (15), or human brain preparations (16). On the basis of the studies mentioned above, it could not be decided whether the low prevalence of antibodies to GAD in the ITA compared with the IPT is due to differences in the source of antigen or to the lower sensitivity of the ITA. In our newly developed ITA using human $\mathrm{GAD}_{65}$, we can detect antibodies in $>85 \%$ of sera that were positive in the IPT. For the first time we demonstrate a strongly positive correlation between the level of antibodies in both assays. With this new assay the ITA achieved a $100 \%$ specificity and a high sensitivity that was only slightly decreased compared with the standard IPT. It is important to emphasize that out of 75 GAD antibody positive sera only 2 sera had high levels in the IPT, being repeatedly negative in the ITA. This suggests the presence of GAD binding antibodies inhibiting the GAD enzyme activity. Furthermore, nine sera with low antibody levels in the IPA were negative in our ITA. These negative results may be explained by the lower sensitivity of the measurement of enzyme activity in the ITA compared with the fluorography technique. As we cannot exclude the presence of antibodies that block GAD enzyme activity in these sera, our data at least indicate that GADblocking antibodies are only present in a minority of patients with IDDM.

In conclusion, antibodies to $\mathrm{GAD}_{65}$ are valuable serological markers for preclinical and overt IDDM, whereas antibodies to $\mathrm{GAD}_{67}$ may be of minor importance. Because GAD-blocking antibodies appear only in a minority of patients with IDDM, the ITA represents a valuable tool for the detection of antibodies to GAD with the advantage of easy performance and quantitative measurement of the autoantibodies. The availability of human recombinant GAD facilitate specific and sensitive screening for antibodies to GAD on large scale and may be useful to determine the role of GAD in the development of IDDM.

\section{Acknowledgments}

We thank Professor G. Adler for continuous support.

The study was supported by the Deutsche Forschungsgemeinschaft Sche 225/6-3 (W. A. Scherbaum), the Deutsche Diabetes Stiftung (J. Seissler), and the Juvenile Diabetes Foundation International (W. A. Scherbaum).

\section{References}

1. Tarn, A. C., J. M. Thomas, B. M. Dean, D. Ingram, G. Schwarz, G. F. Bottazzo, and E. A. M. Gale. 1988. Predicting insulin-dependent diabetes. Lancet. i:845-850.

2. Riley, W. J., N. K. Maclaren, J. Kirscher, R. P. Spillar, J. H. Silverstein, D. A. Schatz, S. Schwartz, J. Malone, S. Shah, C. Vadheim, et al. 1990. A prospective study of the development of diabetes in relatives of patients with insulin-dependent diabetes. $N$. Engl. J. Med. 323:1167-1172.

3. Baekkeskov, S., M. Landin, J. K. Kristensen, S. Srikanta, G. J. Bruining, T. Mandrup-Poulsen, C. de Beaufort, J. S. Soeldner, G. Eisenbarth, F. Lindgren, et al. 1987. Antibodies to a $64,000 \mathrm{Mr}$ human islet cell antigen precede the clinical onset of insulin-dependent diabetes. J. Clin. Invest. 79:926-934.

4. Atkinson, M. A., N. K. Maclaren, D. W. Scharp, P. E. Lacy, and W. J. Riley. 1990. 64,000 Mr autoantibodies as predictors of insulin dependent diabetes. Lancet. i:1357-1360.

5. Bonifacio, E., P. J. Bingley, M. Shattock, B. M. Dean, D. Dunger, E. A. M. Gale, and G. F. Bottazzo. 1990. Quantification of islet-cell antibodies and prediction of insulin-dependent diabetes. Lancet. i:147-149. 
6. Landin-Olsen, M., J. P. Palmer, Å. Lernmark, L. Blom, G. Sundkvist, L. Nyström, and G. Dahlquist. 1992. Predictive value of islet cell and insulin autoantibodies for type 1 (insulin-dependent) diabetes mellitus in a population-based study of newly-diagnosed diabetic and matched control children. Diabetologia. 35:1068-1073.

7. Bärmeier, H., K. McCulloch, J. L. Neifing, G. Warnock, R. V. Rajotte, J. P. Palmer, and Á. Lernmark. 1991. Risk for developing type 1 (insulin-dependent) diabetes mellitus and the presence of islet 64K antibodies. Diabetologia. 34:727733.

8. Seissler, J., B. Hering, W. Richter, M. Glück, N. Yassin, R. G. Bretzel, B. O Boehm, K. Federlin, and W. A. Scherbaum. 1992. Antibodies to the Mr 64,000 (64K) protein in islet cell antibody positive non-diabetic individuals indicate high risk for impaired beta-cell function. Diabetologia. 35:550-554.

9. Baekkeskov, S., A. J. Aanstoot, S. Christgau, A. Reetz, M. Solimena, M. Cascalho, F. Folli, H. Richter-Olesen, and P. De Camilli. 1990. Identification of the $64 \mathrm{~K}$ autoantigen in insulin-dependent diabetes as the GABA-synthesizing enzyme glutamic acid decarboxylase. Nature (Lond.). 347:151-156.

10. Erlander, M. G., N. J. K. Tillakaratne, S. Feldblum, N. Patel, and A. J. Tobin. 1991. Two genes encode distinct glutamate decarboxylases. Neuron. 7:91100 .

11. Karlsen, A. E., W. A. Hagopian, C. E. Grubin, S. Dube, C. M. Disteche, D. A. Adler, H. Bärmeier, S. Mathewes, F. J. Grant, D. Foster, et al. 1991. Cloning and primary structure of a human islet isoform of glutamic acid decarboxylase from chromosome 10. Proc. Natl. Acad. Sci. USA. 88:8337-8341.

12. Christgau, S., H. Schierbeck, H. J. Aanstood, L. Aagaard, K. Begley, H. Kofod, K. Hejnaes, and S. Baekkeskov. 1991. Pancreatic $\beta$ cells express two autoantigenic forms of glutamic acid decarboxylase, a $65-\mathrm{kDa}$ hydrophilic and a 64-kDa amphiphilic form which can be both membrane-bound and soluble. $J$. Biol. Chem. 266:21257-21264.

13. Kaufman, D. L., M. G. Erlander, M. Clare-Salzler, M. A. Atkinson, N. K. Maclaren, and A. J. Tobin. 1992. Autoimmunity to two forms of glutamate decarboxylase in insulin-dependent diabetes mellitus. J. Clin. Invest. 89:283292.

14. Martino, G. V., M. L. Tappaz, S. Braghi, N. Dozio, N. Canal, G. Pozza, G. F. Bottazzo, L. M. E. Grimaldi, and E. Bosi. 1991. Autoantibodies to glutamic acid decarboxylase (GAD) detected by an immunotrapping enzyme activity assay: relation to insulin-dependent diabetes mellitus and islet cell antibodies. $J$. Autoimmun. 4:915-923.

15. Thivolet, C., M. Tappaz, A. Durand, J. Petersen, A. Stefanutti, P. Chatelain, B. Vialettes, W. A. Scherbaum, and J. Orgiazzi. 1992. Glutamic acid decarboxylase (GAD) autoantibodies are additional predictive markers of Type 1 (insulin-dependent) diabetes mellitus in high risk individuals. Diabetologia. 35:570-576

16. De Aizpurua, H. J., Y. M. Wilson, and L. C. Harrison. 1992. Glutamic acid decarboxylase autoantibodies in preclinical insulin-dependent diabetes. Proc. Natl. Acad. Sci. USA. 89:9841-9845.

17. Scherbaum, W. A., W. Hampl, P. Muir, M. Glück, J. Seissler, H. Egle, H. Hauner, B. O. Boehm, E. Heinze, J. E. Banatvala, and E. F. Pfeiffer. 1991. No association between islet cell antibodies and cocksackie $B$, mumps, rubella and cytomegalovirus antibodies in non-diabetic individuals aged $7-19$ years. Diabetologia. 34:835-838
18. Boehm, B. O., B. Manfras, J. Seissler, K. Schöflling, M. Glück, G. Holzberger, S. Seidl, P. Kühnl, M. Trucco, and W. A. Scherbaum. 1991. Epidemiology and immunogenetic background of islet cell antibody-positive nondiabetic schoolchildren. Ulm-Frankfurt population study. Diabetes. 40:1435-1439.

19. Scherbaum, W. A., R. Mirakian, R. Pujol-Borrell, B. M. Dean, and G. F. Bottazzo. 1986. Immunochemistry in the study and diagnosis of organ-specific autoimmune diseases. In Immunochemistry. Modern Methods and Applications. J. M. Polak, and S. Van Noorden, editors. Wright, Bristol, England. 456476.

20. Summers, M. D., and G. E. Smith. 1987. A manual of methods for baculovirus vectors and insect cell culture procedures. Tex. Agric. Exp. Stn. Bull. 1555:1-56.

21. Miller, L. P., D. L. Martin, A. Mazumder, and J. R. Walters. 1978. Studies on the regulation of GABA synthesis: substrate-promoted dissociation of pyridoxal-5'-phosphate from GAD. J. Neurochem. 30:361-369.

22. Gottlieb, D. I., Y.C. Chang, and J. E. Schwob. 1986. Monoclonal antibodies to glutamic acid decarbolxylase. Proc. Natl. Acad. Sci. USA. 83:8808-8812.

23. Kaufman, D. L., C. R. Houser, and A. J. Tobin. 1991. Two forms of the $\gamma$-aminobutyric acid synthetic enzyme glutamate decarboxylase have distinct intraneuronal distribution and cofactor interactions. J. Neurochem. 56:720-723.

24. Christie, M., M. Landin-Olsson, G. Sundkvist, G. Dahlquist, Ȧ. Lernmark, and S. Baekkeskov. 1988. Antibodies to a Mr-64000 islet cell protein in Swedish children with newly diagnosed Type 1 (insulin-dependent) diabetes. Diabetologia. 31:597-602.

25. Deaizpurua, H. J., L. C. Harrison, and D. S. Cram. 1992. An ELISA for antibodies to recombinant glutamic acid decarboxylase in IDDM. Diabetes. 41:1182-1187.

26. Velloso, L. A., O. Kämpe, D. L. Eizirik, A. Hallberg, A. Andersson, and F. A. Karlsson. 1993. Human autoantibodies react with glutamic acid decarboxylase antigen in human and rat but not in mouse pancreatic islets. Diabetes. 36:3946.

27. Christie, M. R., T. J. Brown, and D. Cassidy. 1992. Binding of autoantibodies in sera from type 1 (insulin-dependent) diabetic patients to glutamate decarboxylase from rat tissues. Evidence for antigenic and non-antigenic forms of the enzyme. Diabetologia. 35:380-384

28. Chang, Y. C., and D. I. Gottlieb. 1988. Characterization of the proteins purified with monoclonal antibodies to glutamic acid decarboxylase. J. Neurosci. 8:2123-2130.

29. Wilkin, T. J., S. L. Schönfeld, J. L. Diaz, V. Kruse, E. Bonifacio, and J. P. Palmer. 1989. Systematic variation and differences in insulin-autoantibody measurements. Diabetes. 38:172-181.

30. Richter, W., J. Endl, T. Eiermann, M. Brandt, R. Kientsch-Engel, C. Thivolet, H. Jungfer, and W. A. Scherbaum. 1992. Human monoclonal islet cell antibodies from a patient with insulin-dependent diabetes mellitus reveal glutamate decarboxylase as the target antigen. Proc. Natl. Acad. Sci. USA. 89:84678471.

31. Christie, M. R., D. Daneman, P. Champagne, and T. L. Delovitch. 1990. Persistence of serum antibodies to $64,000 \mathrm{Mr}$ islet cell protein after onset of Type 1 diabetes. Diabetes. 39:653-656.

32. Solimena, M., and P. de Camilli. 1991. Autoimmunity to glutamic acid decarboxylase (GAD) in Stiff-Man syndrome and insulin-dependent diabetes mellitus. Trends Neurosci. 14:452-457. 